\title{
THE IMPACT OF "FAMILY 500+" PROGRAMME ON HOUSEHOLD INCOMES, POVERTY AND INEQUALITY
}

\author{
Michał Brzeziński \\ University of Warsaw, Poland \\ Mateusz Najsztub \\ Centre for Economic Analysis, Szczecin, Poland
}

\section{INTRODUCTION}

The $11^{\text {th }}$ of February 2016 State Aid for Child-Support Act has introduced a child-support benefit in the amount of 500 PLN for the second and subsequent children up to the age of 18 years old (the so called "Family 500 +" programme) into the Polish family support system. After fulfilling the income criterion, the benefit is also granted for the first child. The objective of the programme is "above all financial aid directed towards families raising children", which is intended to reduce the financial burden of families associated with child-care, thereby encouraging decisions to have a larger number of children ${ }^{1}$

The "Family 500 +" programme constitutes a significant expansion of the existing system of family support. It functions separately from the already existing forms of aid, and the child-support benefit is granted independently from transfers such as family allowances or social assistance benefits. The implementation of the programme has raised the total value of already existing financial aid for families by approximately $140 \%$.

According to information from the Ministry of Family, Labour and Social Policy, in May 2017 the programme covered 3,97 million children ( $58 \%$ of all children up to the age of 18 in Poland) from over 2,6 million families ${ }^{2}$. Nearly $60 \%$ of families receives the benefit for their first or only child. This applies to over 1,56 million children, of which 724 thousand are only children.

Since the programme's commencement (1 ${ }^{\text {st }}$ of April 2016) until May 2017 the total sum of aid received by families exceeded 27,2 billion PLN. Approximately 22,9 billion of that sum has been transferred to families within the first year of the program's functioning (by the end of March 2017) ${ }^{3}$. The total handling costs of the programme until May of 2017 equalled to 455 million PLN ${ }^{4}$.

The "Family 500 +" programme has significantly affected the distribution of income in Poland. The aim of this paper is to estimate the short-term impact of this program on the distribution of income and expenditures of households, as well as on poverty and inequality. The object of analysis is poverty in general, as well as the poverty of children and poverty by different types of households.

The paper also attempts to estimate the impact of certain modifications to the "Family $500+$ " programme, as well as, e.g. the implementation of an "upper limit" income criterion, which, when exceeded, results in the complete withdrawal of the child-support benefit. Compared to prior studies of this type (Goraus, Inchauste 2016; Inchauste et al. 2016; Szarfenberg 2017), this paper presents an analysis of the significance of obtained results depending on the application of different equivalence scales, which enable a comparison of the income and expenditures of households of various sizes and in various socio-demographic compositions.

The data set in relation to which the impact of the "Family $500+$ " programme is studied, is the representative database derived from the Household Budgets Survey (BBGD) by GUS (Central Statistics Office) from 2015. This data set contains information regarding 101076 individuals in 37148 households. The BBGD weights made available by GUS have been adjusted by the structure of populace residing within the territory of Poland in 2015 and many other characteristics, in order for the aggregated results to as best as possible reflect information available in administrative data (Myck, Najsztub 2015)5. Individual income has been converted for microsimulation purposes from net income to gross income.
The basis for distributional analyses are the results of the SIMPL static microsimulation model (e.g. Bargain et al. 2007; Morawski, Myck 2010, 2011; Myck 2009; Domitrz et al. 2012). This means that only the direct impact of reforms on the budget of households is taken into consideration, without considering the effects on labour supply.

The base system consists of a tax-benefit system applicable in 2015, expanded by the "złotówka za złotówkę" (a zloty for a zloty) solution for family benefits.

The reformed system originated as a result of expanding the base system with the "Family $500+$ " reform in the wording finally passed by the Polish Sejm. The basis for analyses constitute the disposable income of households reported by GUS and the disposable income of households simulated within the model. The disposable income in the reformed system is calculated as simulated income according to the reformed system less the simulation error, i.e. difference between disposable income according to GUS and the simulated disposable income according to the base system for 2015, without taking into consideration the "Family 500 +" solution. Thanks to this approach it is possible to rank the income according to the GUS definition, while simultaneously utilizing the simulation results.

\section{RULES AND STRUCTURE OF THE "FAMILY 500+" PROGRAMME}

The child-support benefit in the amount of 500 PLN is granted to parents, legal guardians or de facto carers, regardless of the family's income, for the second and subsequent children up to the age of 18 years old. In the event of fulfilling the income criterion income below 800 PLN net per person or 1200 PLN net in case of raising a disabled child - the benefit may also be received for the first or only child in the family. The benefit also applies to children raised in family orphanage, foster families, and education and care centres.

Fulfilment of the income criterion is verified on the basis of the same income category which is applied when granting a family allowance. In the first allowance period (from the $30^{\text {th }}$ of September 2017) fulfilment of the income criterion occurs on the basis of income from the year 2014, applying the regulations on loss or acquisition of income. The project also provides for verification of the income criterion every 3 years - with the first verification to take place on the $1^{\text {st }}$ of October 2019.

The programme's structure does not contain an upper income criterion which would determine the income level of a family which, when exceeded, would result in the benefit being partially or wholly revoked. After the completion of a 3 year period from the implementation of the programme the Council of Ministers is to present a proposal to introduce a fixed uprating mechanism for the amount of the child-support benefit, as well as the income criteria.

The child-support benefit may be granted in a non-monetary form in the event of wastefulness or expenditure contrary to the intended purpose. It is exempt from taxation and is not calculated as part of the income which decides of granting family benefits, housing allowances and social assistance benefits.

The "Family 500 +" programme, therefore, functions independently from existing family support institutions, such as the family benefit system and the PIT system tax credit. Compared to the 
family benefit system, the $500+$ child-care benefit is granted in accordance with separate and distinctive age criteria for children entitled to receive it. There are also other income criteria which determine whether a family is entitled to receive the child-care benefit.

Thereby, the Polish system of financial aid for families now features two active administratively and legally independent instruments which serve practically the same purpose. Apart from complications for families, this also results in additional administrative costs ${ }^{6}$.

Additional doubts may also arise from the fact that the structure of the "Family $500+$ " programme does not provide for higher benefits for children of single parents, although the costs of upbringing children in such families are proportionally higher compared to full families. The benefits for families with disabled children within the programme arise only by way of the higher income threshold for the first or only child - the child-care benefit amount for disabled children is the same as for fully able ones. Finally, the benefit amount is independent from the child's age, even though the costs of upbringing raise with its age (which is taken into consideration, for example, in the structure of the family welfare system).

Apart from the direct impact on increasing the income of households with children and reducing poverty and inequality in society, the "Family $500+$ " programme may also have significant consequences in other areas. Empirical studies conducted for other countries show that financial transfers for families with children may have a positive impact on health, educational results, higher employment and higher pay achieved by such children in the future (Aizer et al. 2016; Carneiro et al. 2015).

On the other hand, the structure of the "Family $500+$ " programme, especially the relatively high benefit amount (approx. $12 \%$ of the average gross wage in 2016) and threshold based benefit revocation for the first child may create disincentives to undertake or continue employment, especially in the case of parents with low income (Blundell et al. 2000; Haan, Myck 2007; Haan, Wrohlich 2011).

The threshold based revocation of the benefit means that if the income per family member exceeds the income criterion adopted in the programme (800 PLN per person or 1200 PLN per person, if the family is raising a disabled child), single child families completely forfeit support arising from the child-care benefit, while families with a larger number of children receive the benefit only for the second and subsequent children. Thereby, families with income per person below 800 PLN receive aid 500 PLN per month higher compared to families with income monthly even minimally exceeding 800 PLN per family member.

The significance of threshold based revocation of the benefit for the first child for the income level with one, two and three children is presented in Figure 1. It illustrates the relation between the gross income from employment and the disposable income in the case of selected types of families. "System 2015" diagram in the figure corresponds to the tax-benefit system, in which the "Family $500+$ " programme is not in effect, while the "System 2015 with $500+$ "

Figure 1. Relation of gross income and disposable income arising from the "Family 500+" programme for different types of families

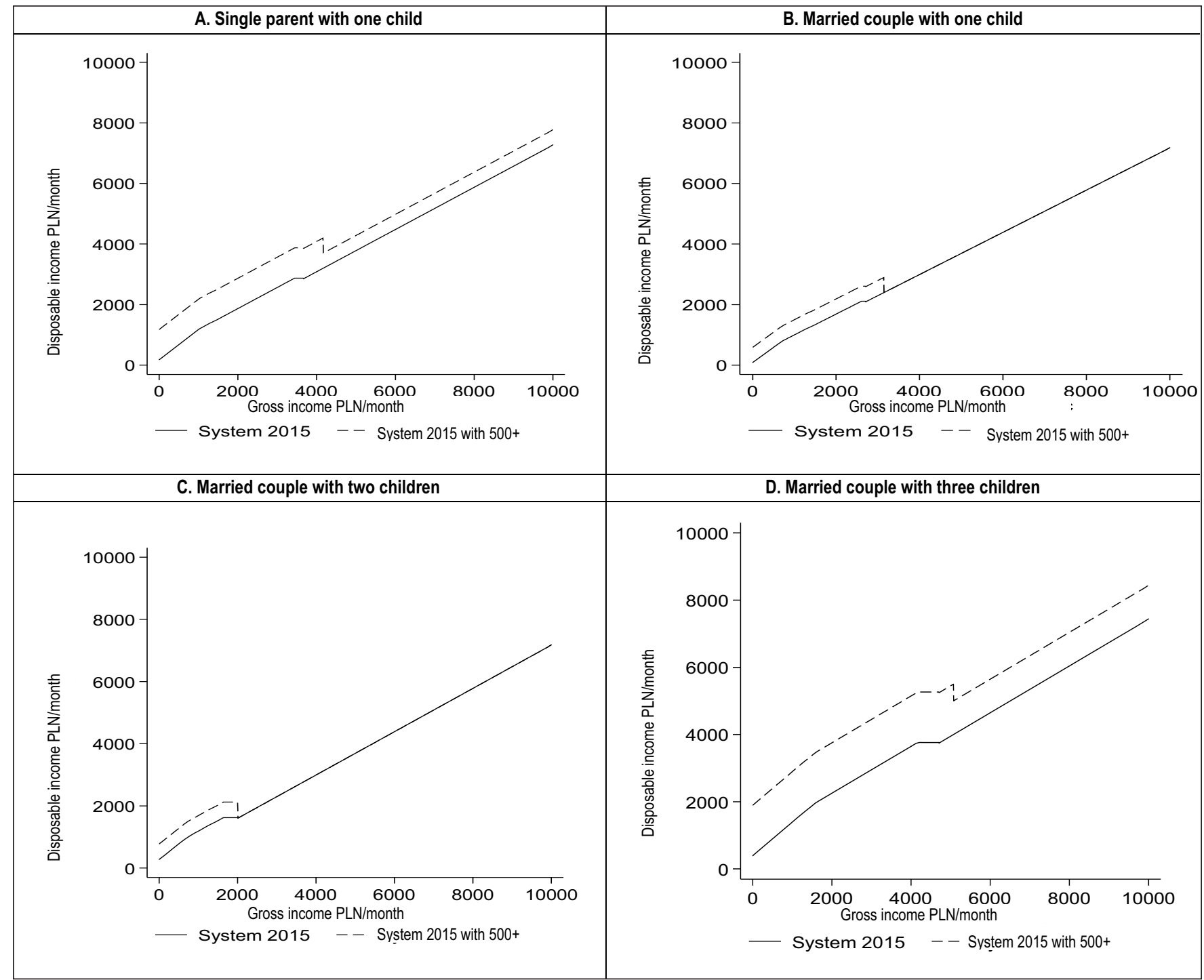


diagram shows a tax-benefit system taking this programme into consideration.

In the case of a single parent with one child, aid from the childcare benefit is revoked completely in the event of gross income from employment exceeding 2000 PLN per month. In the case of married couples with one child, complete revocation of the benefit is effected when income exceeds 3140 PLN gross per month. For married couples with two children where gross income from employment exceeds 4160 PLN, the amount of child-care benefit is limited to 500 PLN per month. In the case of married couples with three children achieving gross income from employment equal to at least 5070 PLN per month, support from the "Family 500+" programme is limited to 1000 PLN per month. In such situations higher employment income leads to a reduction of disposable income, which may result in limiting the occupational activity in families with two working parents - i.e. to one of them resigning

Figure 2 presents a combination of monthly gross income from the parents' employment and information (diagonal lines) regarding the eligibility to receive the child-care benefit for the first child for families with one or more children. The figure shows, for example, that in the case of married couples with one child the child-care benefit is not granted to any family in which both parents work full time (both parents receiving a minimum wage of 1850 PLN gross in 2016), as the family's net income equals 2804 PLN per month, which is 935 PLN per person. If one of the parents receives employment income similar to the average income in the national economy and the second receives the minimum wage, such a family shall receive a child-care benefit for the first child, if they have five or more children in total.

Figure 2. Gross income of parents and eligibility for the child-care benefit for the first child

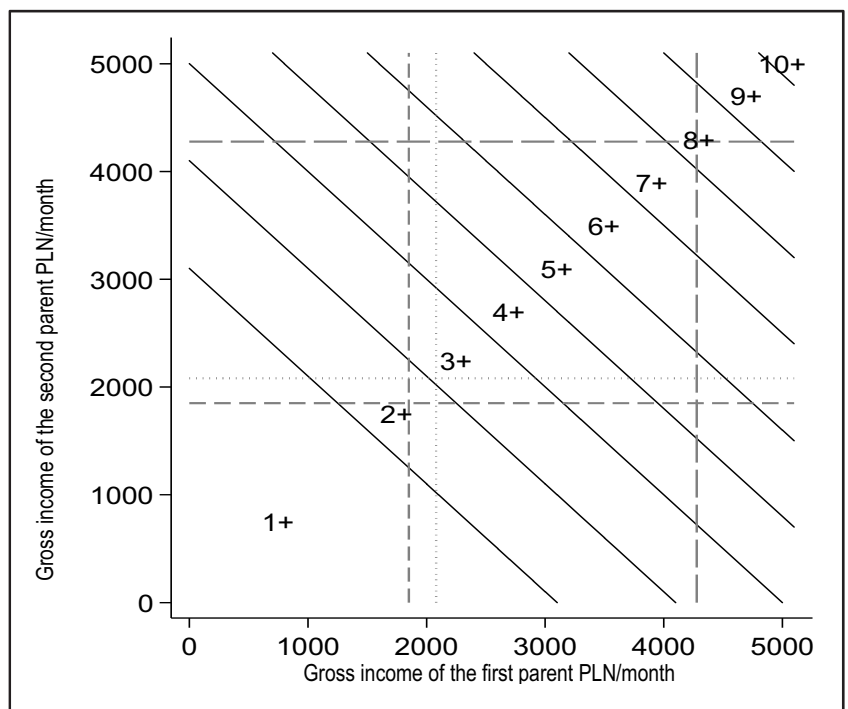

Clarification: The short, broken line shows the minimum wage level (equal to 1850 PLN in 2016), while the long broken line shows the average monthly remuneration level in the national economy in 2016 (4277 PLN). The dotted line presents the proposed minimum wage level for 2018 (2080 PLN). The definition of a child as per the family benefit act is applied.

Source: as per Figure 1.

Figures 1 and 2 illustrate that threshold based withdrawal of the child-care benefit may have negative consequences on the occupational activity of parents. Simulations based on estimating the labour supply when applying the discrete choice model show that ceteris paribus the "Family $500+$ " programme may lead to the withdrawal from the labour market of approximately 235 thousand individuals (Myck 2016). A significant majority of such individuals are women (230 thousand) in families with one or two children, living in rural areas or small towns. The exit from employment may also apply to approximately 25 thousand single parents.
The reduction of employment may result in an increase of the actual costs of the "Family $500+$ " programme for the public finance sector in the long term through lowering the tax revenue and social security contributions. A reduction of market revenues in families reducing the labour supply may lead to a larger number of child-care benefits paid out for the first or only child, as well as an increase in expenditures arising from family benefits.

It appears that a rational move for the future would be to combine elements of the "Family $500+$ " programme with the currently existing system of family benefits into a singular family support instrument. A proposal of this type of synthesis is presented in the study by Myck et al. (2015) as an integrated family benefit $(\mathrm{IFB})^{7}$. A reform of this type would simplify the support system from the perspective of families and provide savings arising from a reduction of administrative costs.

An integrated family benefit would introduce a consolidated age criterion for children covered with the financial aid, a single income threshold and gradual withdrawal of benefits, which would limit the negative impact of the support system on the parents' occupational activity in the labour market. It would also increase the benefits to families with low income, which would contribute to a larger reduction of poverty and inequality. The IFB could be further expanded by an additional support mechanism for families in which both parents are professionally active (Myck et al. 2013). Such an expansion would to a further degree limit the negative impact of reform on the parents' employment.

\section{THE IMPACT OF THE “FAMILY 500+" PROGRAMME ON THE INCOME OF HOUSEHOLDS}

Table 1 illustrates the short-term annual income benefits from the "Family 500 +" programme for households according to income decile groups, calculated for equivalent income. The equivalization has been done using the original OECD equivalence scale. This scale assigns a weight of 1 to the first person in the household aged 14 or above, 0,7 - to any subsequent person aged 14 or more and a weight of 0,5 to any child below the age of $14^{8}$. The total annual cost of the program's operation has been estimated at 24,9 billion PLN. The value of all equivalence scales applied in this article is presented in table 1. It also contains the values of income thresholds for decile groups according to various types of households.

The highest income benefits, absolute as well as proportional to income, fall to households in the first and second income decile group. The poorest $20 \%$ of households receive $42 \%$ of the total financial aid within the scope of the "Family $500+$ " programme. Higher absolute income benefits for households in the lower bracket of equivalent income distribution arise from the concentration of families with a larger number of children in the lower bracket of income distribution, as well as the income criterion which limits eligibility to child-care benefits for the first child in wealthier families.

The income benefits for "higher" decile groups are decreasing, with the exception of the tenth group, for which they are minimally higher than for the ninth group. Households classified as the wealthiest $40 \%$ receive 5,1 billion PLN annually, which is $20,5 \%$ of the total support within the scope of the "Family $500+$ " programme.

The gains from the introduction of the child-care benefit for households with children until 18 years of age are illustrated in table 3. The biggest absolute gains - on average 275 PLN per month in the equivalent income categories - are felt by households with children in the second decile group, while the lowest - on average 79 PLN per month - by households in the ninth decile group. Proportionally to the equivalent income, the highest gains are felt by the poorest households with children, while the lowest gains - by households with the highest income. 
Table 1. Value of the equivalence scale and income thresholds for the income decile groups

\begin{tabular}{|l|c|c|c|c|c|c|c|c|c|c|c|}
\hline \multicolumn{1}{|c|}{ Specification } & \multicolumn{10}{|c|}{ Types of households } \\
\hline Number of people aged $>14$ & 1 & 1 & 1 & 2 & 2 & 2 & 2 & 2 & 3 & 3 & 3 \\
\hline Number of people aged <15 & 0 & 1 & 2 & 0 & 1 & 2 & 3 & 4 & 1 & 2 & 3 \\
\hline Original OECD scale & 1 & 1,5 & 2 & 1,7 & 2,2 & 2,7 & 3,2 & 3,7 & 2,9 & 3,4 & 3,9 \\
\hline Modified OECD scale & 1 & 1,3 & 1,6 & 1,5 & 1,8 & 2,1 & 2,4 & 2,7 & 2,3 & 2,6 & 2,9 \\
\hline Square root scale & 1 & 1,41 & 1,73 & 1,41 & 1,73 & 2 & 2,24 & 2,45 & 2 & 2,24 & 2,45 \\
\hline Subjective scale & 1 & 1,37 & 1,65 & 1,42 & 1,68 & 1,79 & 1,88 & - & - & - & - \\
\hline & & & & & & & & & & & \\
\hline 2 & 862 & 791 & 656 & 900 & 875 & 760 & 620 & 578 & 736 & 693 & 616 \\
\hline 3 & 1100 & 1077 & 705 & 1176 & 1190 & 1006 & 798 & 678 & 917 & 862 & 765 \\
\hline 4 & 1288 & 1240 & 811 & 1390 & 1446 & 1222 & 945 & 724 & 1092 & 1034 & 882 \\
\hline 5 & 1439 & 1369 & 936 & 1585 & 1663 & 1428 & 1112 & 806 & 1267 & 1172 & 1059 \\
\hline 6 & 1600 & 1501 & 1050 & 1777 & 1895 & 1667 & 1255 & 938 & 1438 & 1373 & 1154 \\
\hline 7 & 1794 & 1794 & 1713 & 2134 & 1997 & 2182 & 1912 & 1479 & 1041 & 1645 & 1550 \\
\hline 8 & 2019 & 2019 & 2052 & 2495 & 2280 & 2526 & 2284 & 1787 & 1149 & 1888 & 1765 \\
\hline 9 & 2434 & 2434 & 2333 & 3004 & 2684 & 3085 & 2863 & 2271 & 1376 & 2221 & 2147 \\
\hline 10 & 3195 & 3195 & 3290 & 3978 & 3520 & 4065 & 3920 & 3133 & 1913 & 2911 & 2842 \\
\hline
\end{tabular}

Note: A household is assigned to the decile group $x$, if its disposable income exceeds the threshold for group $x$ and is lower than the threshold of group $x+1$. The values of the subjective scale have been estimated only for certain types of households and are derived from the studies by Kalbarczyk-Stęclik et al. (2017), Miśta and Morawski (2016), Morawski (2016). The values of income thresholds for decile groups have been calculated using the original OECD scale.

Table 2. Annual benefits for households arising from the "Family 500+" programme according to income decile groups

\begin{tabular}{|c|c|c|c|c|c|}
\hline Income decile groups & $\begin{array}{c}\text { Average income without the } \\
\text { Child-care benefit }\end{array}$ & $\begin{array}{c}\text { Average income with the } \\
\text { child-care benefit }\end{array}$ & $\begin{array}{c}\text { Change in income } \\
\text { (PLN/month) }\end{array}$ & $\begin{array}{c}\text { Percentage change in } \\
\text { income }\end{array}$ & $\begin{array}{c}\text { Total annual benefits } \\
\text { (PLN billions) }\end{array}$ \\
\hline 1 & 302,3 & 416,8 & 114,5 & 37,9 & 4.9 \\
\hline 2 & 813,5 & 928,8 & 115,3 & 14,2 & \\
\hline 3 & 1019,3 & 1101,1 & 81,8 & 8,0 & \\
\hline 4 & 1212,5 & 1265,4 & 52,8 & 4,4 & \\
\hline 5 & 1395,7 & 1433,2 & 37,5 & 2,7 & 2.7 \\
\hline 6 & 1593,1 & 1620,8 & 27,8 & 1,7 & 2.0 \\
\hline 7 & 1829,7 & 1853,5 & 23,8 & 1,3 & 1.5 \\
\hline 8 & 2133,8 & 2155,3 & 21,5 & 1,0 & 1.3 \\
\hline 9 & 2659,1 & 2679,4 & 20,3 & & 1.2 \\
\hline 10 & 4966,3 & 4993,2 & 26,8 & & 1.1 \\
\hline
\end{tabular}

Note: equivalent income, original OECD scale.

Source: as per Figure 1.

Table 3. Annual benefits for households with children arising from the "Family 500+" programme according to income decile groups

\begin{tabular}{|c|c|c|c|c|}
\hline Income decile groups & $\begin{array}{c}\text { Average income without the } \\
\text { Child-care benefit }\end{array}$ & $\begin{array}{c}\text { Average income with the } \\
\text { child-care benefit }\end{array}$ & $\begin{array}{c}\text { Change in income } \\
\text { (PLN/month) }\end{array}$ & Percentage change in income \\
\hline 1 & 348,5 & 612,5 & 264,0 & 75.8 \\
\hline 2 & 811,1 & 1085,7 & 274,6 & 33.9 \\
\hline 3 & 1018,4 & 1245,3 & 226,9 & 22.3 \\
\hline 4 & 1210,1 & 1380,0 & 169,9 & 14.0 \\
\hline 5 & 1391,8 & 1522,0 & 130,2 & 9.4 \\
\hline 6 & 1589,3 & 1698,7 & 109,4 & 6.9 \\
\hline 7 & 1831,3 & 1924,8 & 93,5 & 5.1 \\
\hline 8 & 2139,9 & 2224,8 & 84,8 & 4.0 \\
\hline 9 & 2670,1 & 2749,3 & 79,2 & 3.0 \\
\hline 10 & 4872,7 & 4957,0 & 84,3 & \\
\hline
\end{tabular}

Note: equivalent income, original OECD scale.

Source: as per Figure 1.

\section{IMPACT OF THE PROGRAMME ON INCOME AND CONSUMPTION POVERTY}

The short-term impact of the "Family $500+$ " programme on relative income poverty and extreme consumption poverty shall be analysed for the income and expenditures of households equalized using various equivalence scales. As shown by prior studies (see, e.g. Buhmann et al. 1998, Kalbarczyk-Stęclik et al. 2017), poverty measures and ranking of socio-economic groups according to poverty rates vary in a significant way depending on the adopted equivalence scale.

Economic literature does not provide explicit arguments in favour of choosing the best scale, rather recommending a complementary application of various equivalence scales and verification whether the results of distribution analyses are independent of the choice of scale (Coulter et al. 1992; Garner, Short 2003). As a re- 
sult, in the article's analysis of the "Family 500+" programme's impact on poverty and inequality is conducted using the following equivalence scales: the original OECD scale, modified OECD scale, square root scale and subjective scale.

Both OECD scales belong to so called expert scales, whose values are determined by experts and the marginal upkeep cost of additional individuals in the household is independent from the size of the household (see Table 1). The original OECD scale is used, among others, in GUS studies regarding poverty in Poland (see, e.g. GUS 2017b).

The studies of the "Family $500+$ " programme's impact on poverty and inequality in Poland conducted so far have incorporated only the original OECD equivalence scale (see Goraus-Tańska, Inchauste 2016). The modified OECD equivalence scale is commonly used in income and expenditure distribution analyses, as well as GUS analysis of BBGD data.

The simple square root scale, which is often used in international comparative studies, adopts values equal to the square root of the total number of household members. On the other hand the subjective equivalence scale is estimated on the basis of declarations from various types of households with the minimum income necessary to "make ends meet" (Bishop et al. 2014; Kalbarczyk-Stęclik et al. 2017).

The subjective scale has only recently been gaining popularity among researchers - its advantages include, among others, the fact that it adopts different values for different countries, which allows to partially take into consideration the difference in cultural factors influencing the subsistence costs of additional people in the household. The values adopted by subjective equivalence scales are usually, also in the case of Poland, lower than values adopted by other scales. This means that the subjective scales implicate higher benefits of scale within a household and lower marginal costs of a child's upkeep in the household.

The short-term impact of the "Family $500+$ " programme on relative income poverty according to household types and depending on equivalence scale is illustrated in table 4 . Within the entire population as well as among households with children the introduction of the child-care benefit results in a significant reduction in relative income poverty.

Within the entire group of households with children, regardless of the choice of equivalence scale, the level of relative income poverty after the introduction of the benefit is reduced below the level of poverty characteristic of the entire population, as well as individuals living alone. The rates of poverty decrease significantly regardless of the number of children in a household - for the modified OECD scale and square root scale the final poverty rate for households with four and more children is also lower than the poverty rate for the entire population, as well as individuals living alone.

The percentage changes to relative income poverty as a result of introducing the child-care benefit are shown in Figure 3. Among the entire population, regardless of the applied equivalence scale, the introduction of the child-care benefit reduces the relative income poverty by approximately $30-33 \%$ (e.g. from $18.5 \%$ to $12.3 \%$ in the case of the original OECD scale). In the population of children this reduction reaches $64-71 \%$, while for single parents 75-89\%. The comparatively lowest relative reduction in income poverty applies to households with one child - it fluctuates between $34 \%$ and $41 \%$.

Table 4. Impact of the "Family $500+$ " programme on the rate of relative income poverty depending on the adopted equivalence scale, in \%

\begin{tabular}{|c|c|c|c|c|c|c|}
\hline \multirow{3}{*}{ Type of household } & \multicolumn{2}{|c|}{ Original OECD scale } & \multicolumn{2}{|c|}{ Modified OECD scale } & \multicolumn{2}{|c|}{ Square root scale } \\
\hline & before $500+$ & after $500+$ & before $500+$ & after $500+$ & before $500+$ & after $500+$ \\
\hline & \multicolumn{6}{|c|}{ in $\%$} \\
\hline All & 18.5 & 12.3 & 17.8 & 12.3 & 17.5 & 12.2 \\
\hline Individuals living alone & 11.1 & 11.1 & 18.4 & 18.4 & 26.0 & 26.0 \\
\hline Couple without children & 9.7 & 9.7 & 9.9 & 9.9 & 12.1 & 12.1 \\
\hline Individuals living alone aged 65+ & 5.7 & 5.7 & 14.5 & 14.5 & 24.1 & 24.1 \\
\hline Households with children & 23.4 & 10.4 & 20.2 & 8.6 & 18.2 & 7.1 \\
\hline Single parents & 22.7 & 2.4 & 20.0 & 2.7 & 35.1 & 8.6 \\
\hline Households with 1 child & 17.9 & 11.8 & 16.9 & 10.5 & 15.7 & 9.3 \\
\hline Households with 2 children & 24.1 & 8.8 & 19.9 & 7.2 & 18.0 & 6.0 \\
\hline Households with 3 children & 32.3 & 8.4 & 26.2 & 5.3 & 22.7 & 3.3 \\
\hline Households with 4+ children & 61.3 & 15.4 & 48.7 & 6.9 & 39.2 & 1.3 \\
\hline Children & 24.0 & 8.6 & 12.7 & 4.3 & 8.5 & 2.5 \\
\hline
\end{tabular}

Note: The poverty line is equal to $60 \%$ of the median equivalent income.

Source: as per Figure 1.

Figure 3. Percentage reduction in the rate of relative income poverty as a result of the "Family $500+$ " programme depending on the applied equivalence scale (by household type)

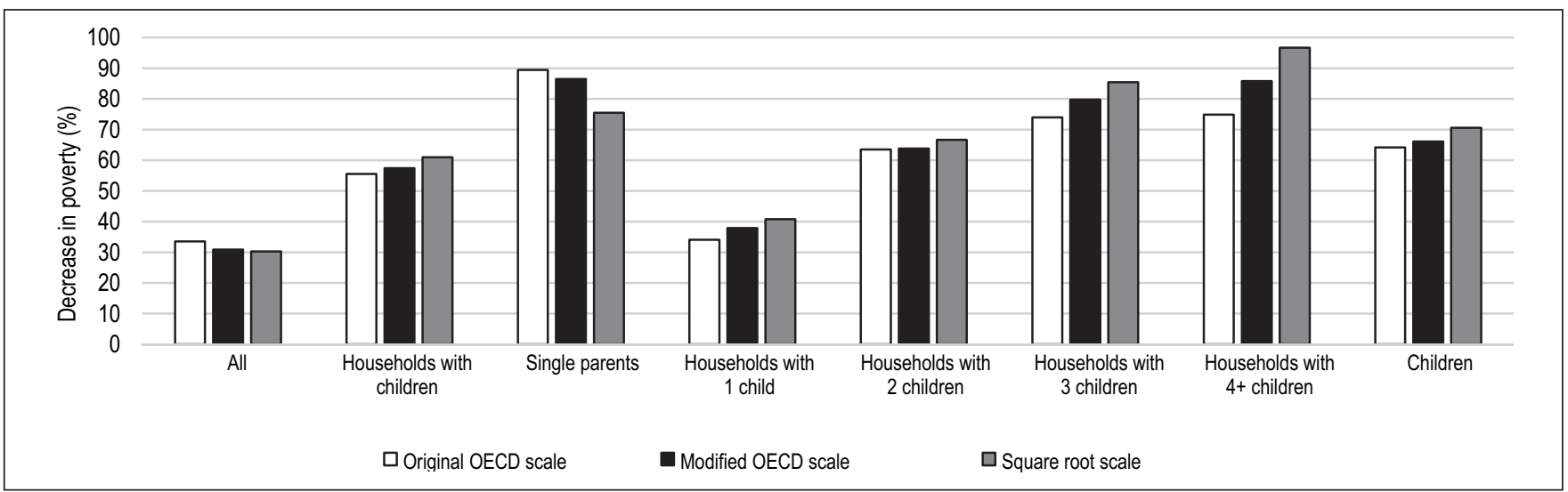

Source: as per Figure 1. 
Compared to monetary based child-support systems in other countries, the "Family 500+" programme rather significantly reduces relative income poverty. The study conducted by Popowa (2016) indicates that monetary transfers for children in Belgium, Sweden, Germany, Great Britain and Russia have in 2010 reduced relative income poverty of the entire population in a range from $2 \%$ to $29,8 \%$, while child poverty - in a range from 5 to $58.1 \%$. Simultaneously, the "Family $500+$ " programme is characterized by moderate vertical effectiveness (percentage of the total programme budget which reaches the poor). In the case of the "Family $500+$ " programme this indicator is $37.3 \%$ while for similar benefits in Great Britain it has reached a value of up to $57.2 \%$.

Results related to the impact of introducing the child-care benefit on the rate of extreme income poverty are presented in tables
5-7 and Figures 3-4. In order to evaluate the impact of the "Family 500 + " programme on extreme income poverty, in accordance with prior literature (Goraus-Tańska, Inchauste 2016), two scenarios have been assumed:

1) increasing family's expenditures by the total amount of the income arising from the child-care benefit (tab. 5-6 and Figure 3);

2) increasing a family's expenses by a part of the amount equal to the share of expenses in a household's income prior to implementation of the reform (Table 7 and Figure 4$)^{9}$.

Table 5 and Figure 3 show that in the case of a scenario of spending the entire child-care benefit for consumption the rate of extreme consumption poverty within the entire population decreases in a range from $35 \%$ to $47 \%$, depending on the applied equivalence scale. Results for the square root scale illustrate

Table 5. Impact of the "Family 500+" programme on the rate of extreme consumption poverty (various equivalence scales) - scenario of allocating the entire child-care benefit to expenses, in \%

\begin{tabular}{|c|c|c|c|c|c|c|}
\hline \multirow{3}{*}{ Type of household } & \multicolumn{2}{|c|}{ Original OECD scale } & \multicolumn{2}{|c|}{ Modified OECD scale } & \multicolumn{2}{|c|}{ Square root scale } \\
\hline & before $500+$ & after $500+$ & before $500+$ & before $500+$ & after $500+$ & before $500+$ \\
\hline & \multicolumn{6}{|c|}{ in $\%$} \\
\hline All & 8.1 & 4.3 & 3.5 & 1.9 & 1.7 & 1.1 \\
\hline Individuals living alone & 3.9 & 3.9 & 3.9 & 3.9 & 3.9 & 3.9 \\
\hline Couple without children & 3.5 & 3.5 & 2.0 & 2.0 & 1.6 & 1.6 \\
\hline Individuals living alone aged 65+ & 3.1 & 3.1 & 3.1 & 3.1 & 3.1 & 3.1 \\
\hline Households with children & 10.2 & 2.0 & 3.8 & 0.3 & 1.3 & 0.0 \\
\hline Single parents & 3.2 & 0.2 & 1.2 & 0.2 & 1.3 & 0.2 \\
\hline Households with 1 child & 7.4 & 2.8 & 2.7 & 0.6 & 1.1 & 0.1 \\
\hline Households with 2 children & 9.8 & 1.7 & 4.0 & 0.0 & 1.6 & 0.0 \\
\hline Households with 3 children & 14.9 & 0.1 & 3.3 & 0.0 & 1.3 & 0.0 \\
\hline Households with $4+$ children & 36.1 & 0.3 & 15.7 & 0.3 & 1.5 & 0.0 \\
\hline Children & 10.0 & 1.3 & 3.6 & 0.2 & 1.3 & 0.0 \\
\hline
\end{tabular}

Note: the poverty line is equal to the subsistence minimum for a single employed person household in 2015 (545,76 PLN).

Source: as per Figure 1.

Figure 4. Percentage decrease of the extreme consumption poverty rate as a result of the "Family 500+" programme depending on the equivalence scale (by household type) - scenario of spending the entire child-care benefit on consumption

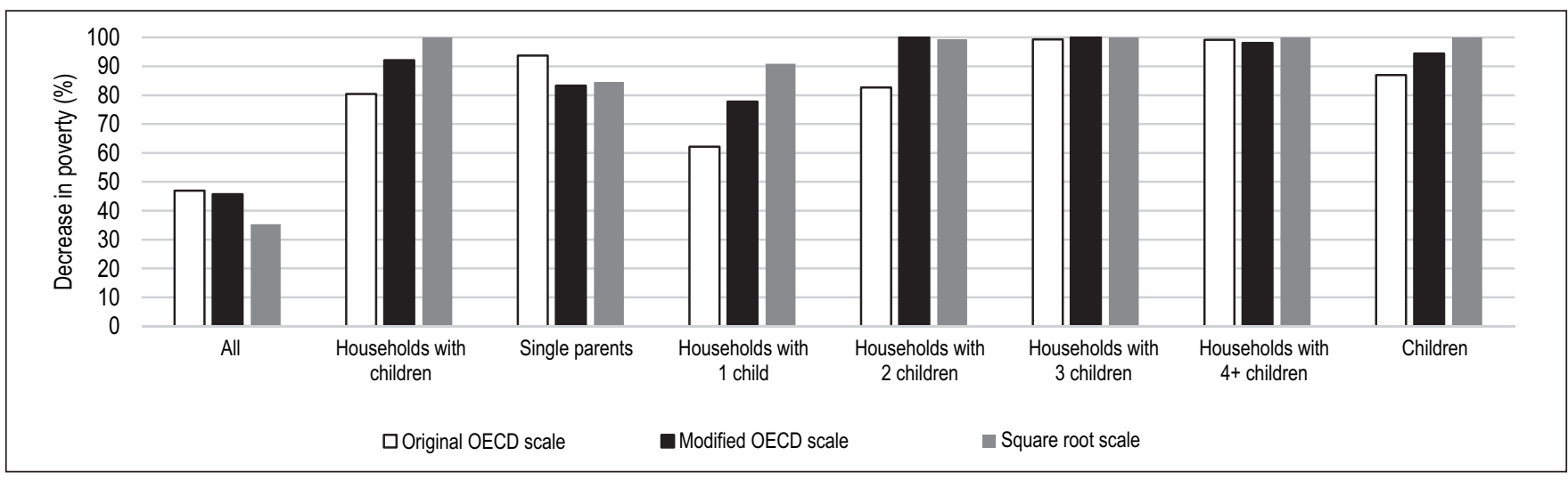

Source: as per Figure 1.

Table 6. Impact of the "Family 500+" programme on the rate of extreme consumption poverty (scenario of allocating the entire child-care benefit to expenses) - comparison taking into account the subjective equivalence scale, in \%

\begin{tabular}{|c|c|c|c|c|c|c|c|c|}
\hline \multirow{3}{*}{ Type of household } & \multicolumn{2}{|c|}{ Original OECD scale } & \multicolumn{2}{|c|}{ Modified OECD scale } & \multicolumn{2}{|c|}{ Square root scale } & \multicolumn{2}{|c|}{ Subjective scale } \\
\hline & before $500+$ & after $500+$ & before $500+$ & after $500+$ & before $500+$ & after $500+$ & before $500+$ & after $500+$ \\
\hline & \multicolumn{8}{|c|}{ in $\%$} \\
\hline Single parent with 1 child & 2.4 & 0.3 & 1.5 & 0.3 & 1.8 & 0.3 & 1.5 & 0.3 \\
\hline Single parent with 2 children & 2.4 & 0.0 & 1.0 & 0.0 & 1.0 & 0.0 & 1.0 & 0.0 \\
\hline Two adults + 1 child & 2.4 & 0.3 & 0.9 & 0.0 & 0.7 & 0.0 & 0.4 & 0.0 \\
\hline Two adults +2 children & 4.6 & 0.0 & 1.5 & 0.0 & 1.0 & 0.0 & 0.8 & 0.0 \\
\hline Two adults +3 children & 9.2 & 0.0 & 1.5 & 0.0 & 0.8 & 0.0 & 0.6 & 0.0 \\
\hline
\end{tabular}

Note: the poverty line is equal to the subsistence minimum for a single employed person household in 2015 (545,76 PLN).

Source: as per Figure 1. 
complete elimination of extreme poverty in households with children and among children, while results incorporating other scales suggest a decrease in extreme poverty among those groups in a range from $80 \%$ to $94 \%{ }^{10}$. A clearly smaller reduction of extreme poverty is visible only in the case of households with one child (a decrease by $62 \%$ when using the original OECD scale).

It is worth noting that the estimations of poverty rates for households with children (before considering aid from the childcare benefit) are clearly lower for the modified OECD scale and square root scale, compared to the original OECD scale. In the case of households with four and more children the rate of extreme poverty by expenses equalized using the original OECD scale is $36.1 \%$, while in the other two cases it is $15.7 \%$ (modified OECD scale) and only $1.5 \%$ (square root scale).

Similarly low extreme poverty rate values among households with children as in the case of applying the square root scale are achieved when using the subjective scale (Table 6). Among the applied equivalence scales, the original OECD scale provides for the lowest economies of scale in a household and highest marginal cost of child upbringing in a household.

On the other hand, the subjective scale estimated based on declarations of households with the minimum income necessary to "make ends meet" implies, in the case of Poland, higher economies of scale and a lower marginal cost of child upbringing (see Kalbarczyk-Stęclik 2017 and Table 1). Application of the subjective equivalence scale, therefore, leads to results presenting lower poverty rates among households with a larger number of members (including children) as compared to households with a lower number of members.
Those results suggest that often quoted opinions regarding the immensely high degree of extreme poverty among Polish children prior to the introduction of the "Family $500+$ " programme could have been based on studies incorporating only the original OECD equivalence scale.

It seems that in the future analyses and studies of poverty by household types in Poland should incorporate various types of equivalence scales (including the subjective scales).

As shown in Table 5, after implementation of the "Family 500+" programme the rates of extreme consumption poverty among households with children have decreased below the levels reached by households of persons living alone and childless couples ${ }^{11}$.

This conclusion is independent from the equalisation method of household income. This means, that after introduction of the child-care benefit the objective of social policy preventing extreme poverty should probably rather be households with fewer members (single-person, childless couples, married couples with one child).

Table 7 and Figure 5 present the impact of the "Family $500+$ " programme on extreme consumption poverty with the assumption that households spend only part of the child-support benefit, equal to the expenditures to income ratio from the period prior to introduction of the benefit. In this case the reduction of extreme poverty is obviously smaller than in the case of spending the entire benefit amount on consumption. The extreme poverty rate within the entire population has seen a decrease in a range from 35\% to $40 \%$ depending on the applied equivalence scale. In the case of children this reduction ranges from $75 \%$ to $92 \%$.

Table 7. Impact of the "Family 500+" programme on the rate of extreme consumption poverty (various equivalence scales) - scenario of spending a part of the child-care benefit equal to the expenditures to income ratio of a household, in \%

\begin{tabular}{|c|c|c|c|c|c|c|}
\hline \multirow{3}{*}{ Type of household } & \multicolumn{2}{|c|}{ Original OECD scale } & \multicolumn{2}{|c|}{ Modified OECD scale } & \multicolumn{2}{|c|}{ Square root scale } \\
\hline & before $500+$ & after $500+$ & before $500+$ & before $500+$ & after $500+$ & before $500+$ \\
\hline & \multicolumn{6}{|c|}{ in $\%$} \\
\hline All & 8.1 & 4.9 & 3.5 & 2.2 & 1.7 & 1.1 \\
\hline Individuals living alone & 3.9 & 3.9 & 3.9 & 3.9 & 3.9 & 3.9 \\
\hline Couple without children & 3.5 & 3.5 & 2.0 & 2.0 & 1.6 & 1.6 \\
\hline Individuals living alone aged 65+ & 3.1 & 3.1 & 3.1 & 3.1 & 3.1 & 3.1 \\
\hline Households with children & 10.2 & 3.3 & 3.8 & 1.0 & 1.3 & 0.1 \\
\hline Single parents & 3.2 & 0.2 & 1.2 & 0.2 & 1.3 & 0.2 \\
\hline Households with 1 child & 7.4 & 3.8 & 2.7 & 1.3 & 1.1 & 0.2 \\
\hline Households with 2 children & 9.8 & 3.2 & 4.0 & 0.9 & 1.6 & 0.0 \\
\hline Households with 3 children & 14.9 & 1.7 & 3.3 & 0.3 & 1.3 & 0.1 \\
\hline Households with 4+ children & 36.1 & 2.5 & 15.7 & 0.3 & 1.5 & 0.0 \\
\hline Children & 10.0 & 2.5 & 3.6 & 0.7 & 1.3 & 0.1 \\
\hline
\end{tabular}

Note: the poverty line is equal to the subsistence minimum for a single employed person household in 2015 (545,76 PLN).

Source: as per Figure 1.

Figure 5. Percentage decrease in the rate of extreme consumption poverty as a result of the "Family 500+" programme depending on the equivalence scale (by household type) - scenario of spending a part of the total child-care benefit

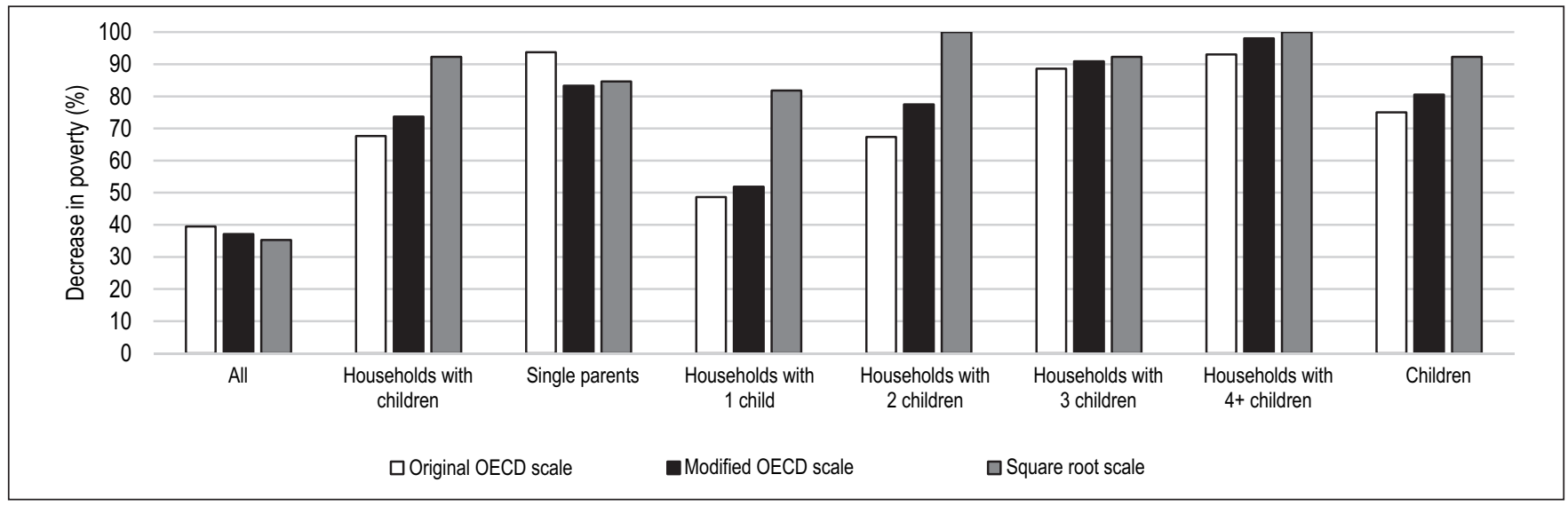

Source: as per Figure 1 
Table 8. Impact of the "Family 500+" programme on income and expenditure inequalities (the Gini inequality index)

\begin{tabular}{|l|c|c|c|c|c|}
\hline \multirow{2}{*}{ Equivalence scale } & \multicolumn{2}{|c|}{ Equivalent Income } & \multicolumn{3}{c|}{ Equivalent Expenditures } \\
\cline { 2 - 6 } & before 500+ & after 500+ & before 500+ & $\begin{array}{c}\text { after 500+ (scenario of spending the } \\
\text { entire child-care benefit) }\end{array}$ & $\begin{array}{c}\text { after 500+ (scenario of spending } \\
\text { part of the child-care benefit) }\end{array}$ \\
\hline OECD & 0.347 & 0.322 & 0.323 & 0.298 & 0.303 \\
\hline Modified OECD & 0.343 & 0.320 & 0.315 & 0.294 & 0.299 \\
\hline Square root & 0.336 & 0.314 & 0.305 & 0.284 & 0.289 \\
\hline
\end{tabular}

Note: Negative income values have been replaced with 0 .

Source: as per Figure 1.

The GUS lead study devoted to measuring poverty in Poland in 2016 indicates that the rate of extreme consumption poverty - for expenses equalised using the original OECD scale - has been reduced among the entire population in that year from $6.5 \%$ to $4.9 \%$ (a decrease by $25 \%$ ), and among children from $9 \%$ to $5.8 \%$ (a decrease by 36\%) (GUS 2017b). These decreases are lower than shown by estimations of the "Family $500+$ " programme's impact on extreme consumption poverty previously presented in this and prior studies utilising the microsimulation approach. These discrepancies may be caused by many factors.

Firstly, they may arise from a different methodology of measuring poverty.

Secondly, changes in poverty measured by GUS arise not only from the impact of the "Family $500+$ " programme, but also from the impact of market forces (changes to market revenues) and elements of transfer policy other than the child-care benefit.

Thirdly, microsimulation studies devoted to the impact of the "Family 500+" programme utilized BBGD data from the years 2014-2015, while the programme has in actuality been implemented in the year 2016, in the wake of realistically growing incomes and expenses of households compared to prior years.

Fourthly, in 2016 the "Family 500 +" programme has been in force only since April and expenditures arising from the programme in April were still minor.

Fifthly, the households could allocate a larger part of the benefit than assumed in microsimulation studies on payment of obligations or increasing their savings.

The reconciliation of microsimulation analyses results with changes observed by GUS will be possible in the future after GUS has made available the BBGD microdata for the 2016 and subsequent years.

\section{IMPACT OF THE PROGRAMME ON INCOME AND CONSUMPTION INEQUALITY}

Table 8 illustrates the short-term impact of introducing the child-care benefit on income and consumption inequality measured using the Gini index. Income inequalities decrease in a range of $6.5-7.2 \%$, while consumption inequalities decrease in a range from $5.1 \%$ to $7.7 \%$ depending on the equivalence scale and expenditure degree of the child-care benefit amount ${ }^{12}$. It can, therefore, be assumed that the initially observed (GUS 2017a) decrease in income inequality (Gini index) in 2016 by approximately $6 \%$ is in part associated with the implementation of the "Family $500+$ " programme.

It should, however, be noted that income inequalities in Poland measured using GUS survey data have been decreasing slowly as far back as 2005 (Myck, Najsztub 2016). This is primarily a result of the decreasing education bonus at the time and reforms of the taxbenefit system implemented in years 2006-2008 and 2012-2014.

The progressive impact of the child-care benefit on income and expenditure inequality in Poland may be limited in the long-term, if the abovementioned negative consequences of the "Family $500+$ " programme on the labour market activity of parents occur. In households which would be affected by this issue labour income could be decreased significantly and over a long term, which would further contribute to stratification in society.
Additionally, as shown by Inchauste et al. (2016), the "Family $500+$ " programme may also contribute to an increase in intergenerational inequality, as in all probability the support from childcare benefits will more often be invested in higher quality preschool, school and extracurricular education by families with higher income.

\section{DISTRIBUTION IMPACT OF CERTAIN MODIFICATIONS TO THE "FAMILY 500+" PROGRAMME}

Presented below are estimations of the distributional impact of certain simple modifications to the "Family $500+$ " programme. As shown previously, the programme to a significant degree reduces extreme poverty, especially among children, in Polish society. It does not, however, eliminate it completely. The cost of hypothetically raising the expenditure of all households in Poland to the level of the extreme poverty line, with the assumption that the entirety of the support received by poor households would be spent, is 11,4 billion PLN per year, which is $46 \%$ of the total annual support within the scope of the "Family $500+$ " programme ${ }^{13}$. In the case of extreme poverty among children, this cost is 3,1 billion PLN per year (12,4\% of the total annual costs of the "Family $500+$ " programme).

These results illustrate that the elimination of extreme poverty of children, which is often invoked in Polish public discourse as a consequence of the "Family $500+$ " programme, could be hypothetically achieved by spending approximately $1 / 8$ of the amount of funds allocated to the child-care benefit. Evaluating this conclusion it is necessary to remember, however, that the assumed objectives of the programme of supporting not only families living in extreme poverty.

Public debate also frequently refers to the possibility of modifying the "Family $500+$ " programme by implementing an "upper" income criterion which, when exceeded, would result in a gradual or complete withdrawal of the benefit. According to information provided by Bartosz Marczuk, secretary of state at the Ministry of Family Labour and Social Policy, the complete withdrawal of the child-care benefit with an upper income threshold of 5000 PLN monthly per person would reduce expenses arising from the programme by 81 million PLN with an administrative cost of this operation equal to 76 million PLN ${ }^{14}$. Table 9 presents the estimated benefits for the public finance sector arising from supplementing the "Family 500+" programme with an upper income threshold, which would cause complete withdrawal of the benefit when exceeded.

Table 9. Gains to the public finance sector arising from completely withdrawing the child-care benefit after exceeding the upper income threshold

\begin{tabular}{|c|c|}
\hline $\begin{array}{c}\text { Upper income threshold amount } \\
\text { (in PLN monthly per person) }\end{array}$ & $\begin{array}{c}\text { Budget gains } \\
\text { in PLN billions annually }\end{array}$ \\
\hline 5000 & 0,104 \\
\hline 4000 & 0,188 \\
\hline 3000 & 0,521 \\
\hline 2000 & 1,484 \\
\hline
\end{tabular}

Note: the estimations of benefits presented in the table do not take into account administrative costs of introducing the upper income threshold.

Source: as per Figure 1. 
The analysis results show that indeed, in case of a benefit withdrawal threshold equal to 5000 PLN per person, the benefits to the public finance sector are quite low. This threshold, however, seems to be relatively high - exceeding it by a married couple with two children would mean earning a monthly disposable net income of 20 thousand PLN.

Establishment of a benefit revocation threshold at a lower level brings measurably higher budget gains. For example, the 2000 PLN monthly per person threshold generates gains in the amount of 1,5 billion PLN annually. This amount is higher than, e.g. the amount of state budget subsidies to the National Centre for Research and Development or National Centre for Science in 2016. Such savings would also enable coverage of a significant part of the costs of supplementing the "Family $500+$ " programme by the "zloty for a zloty" mechanism (cost equal to 1,78 billion PLN annually).

\section{CONCLUSIONS}

The article utilizes BBGD 2015 data and the microsimulation approach in order to estimate the short-term impact of the "Family $500+$ " programme on the income of households, poverty and inequality.

The results show that the child-care benefit will to the largest degree increase the income of households situated in the lower bracket of income distribution. Depending on the method of equivalising the household expenses and method of spending the childsupport benefit funds, extreme consumption poverty among the entire population should decrease in a range from $3 \%$ to $47 \%$, while among children - in a range of $75-100 \%$.

Results also suggest that the "Family 500 +" programme shall reduce income inequalities in Poland measured by the Gini index by several percent. In reality, the impact of the child-care benefit on the distribution of income and expenses in 2016 may be lower than indicated by estimations presented in this article, which are based on microdata from the year 2015. It appears, however, that the estimated impact of reducing the extreme poverty rates are high enough, that the error arising from the increase in household income in the 2015-2016 period is relatively minor.

The results according to which implementation of the "Family $500+$ " programme may lead to households with children, especially more than one child, to be at a higher risk of extreme poverty compared to smaller households appear especially interesting from the perspective of social policy recommendations.

What is more, analysis based on utilising certain equivalence scales suggests that even prior to implementing the child-care benefit the extreme poverty rates among households with children in Poland were at a level comparable or lower than among singleperson households or childless couples.

It should also be emphasized, that the short-term progressive impact of the "Family $500+$ " programme on income distribution in Poland may be limited in the long term, if the potentially negative consequences of the programme for the occupational activity of low income parents come into effect.

Justification to the $11^{\text {th }}$ of February 2016 State Aid for Child-Support act, https://legislacja.rcl.gov.pl/docs//2/12279566/12326797/12326798/ dokument202543.pdf [accessed on 2.08.2017].

2 http://www.mpips.gov.pl/aktualnosci-wszystkie/rodzina-500-plus/ art,8949,prawie-4-mln-dzieci-z-rodzina-500.html [accessed on 2.08.2017].

This constitutes $1,2 \%$ of Poland's GDP in 2016.

4 MRPiPS information published on Twitter: https://twitter.com/MRPiPS GOV PL/status/887212667940818944.

Apart from the age structure, also the number of taxpayers, number of payers of healthcare insurance broken down into employees and selfemployed, number of individuals receiving a pension or retirement, number of registered unemployed and number of individuals with high income has been subject to adjustment.

6 The administrative cost of the "Family $500+$ " programme in the period from the $1^{\text {st }}$ of April 2016 to the end of May 2017 was approximately 455 million PLN. This constitutes approximately $1.7 \%$ of the expenses incurred as part of the programme.

A simpler instrument limiting the negative income consequences arising from the threshold based revocation of child-care benefits would be the "zloty for a zloty" system which has since January 2016 been an element of the family benefits system. This solution would increase the costs of the "Family $500+$ " programme by approximately 1,78 billion PLN per year.

8 The equivalence scales make it possible to compare the welfare of households of various sizes and different socio-demographic composition by taking into consideration the benefits of scale and needs of individuals of various ages. In practice these are factors, by which the total income of a household of a different size and composition is divided in order to obtain an equivalent income comparable between households.

9 A comparison taking into consideration the subjective equivalence scale is presented only for scenario 1 and included in table 6 , as the values of the subjective scale have been estimated only for certain types of households (see Kalbarczyk-Stęclik et al. 2017; Miśta and Morawski 2016; Morawski 2016)

10 This result corresponds to results of prior analyses, according to which the decrease in the rate of extreme consumption poverty among children shall in the discussed case be $94 \%$ (see Szarfenberg 2017).

11 In most cases (apart from households with 1 child and analysis based on OECD equivalence scales), this conclusion applies also in the case of the partial child-care benefit scenario (see tab. 7).

12 These results correspond to previous results by Inchauste et al. (2016), and Goraus-Tańskiej and Inchauste (2016). According to the first of those studies, the "Family $500+$ " programme will reduce income inequalities measured by the Gini index by $6.7 \%$, while according to the second study - by $8.5 \%$. Monetary transfers for children in Western European countries will reduce the Gini index value for income equalised using the original OECD scale in a range of $4.5 \%$ (Sweden) to $9.2 \%$ (Belgium) (Popowa 2016).

13 It is an estimation of the static impact of monetary transfers for people in extreme poverty, which do not consider the impact of such transfers on the labour supply among the poor. Collado et al. (2017) have recently studied the issue of eliminating relative poverty in Belgium, Denmark and Great Britain in a way which would not reduce incentives to take on occupational activity among people in poverty. The cost of such a reform turned out to be twice as high, as the cost needed to mechanically increase the income of all households to the level of the relative poverty line.

14 Vice-minister in charge of 500+. Bartosz Marczuk: Oczywiście, że wezme pieniądze z programu lOf course I will take money from the programme], interview with Bartosz Marczuk conducted by Magdalena Rigamonti, „Dziennik” dated 1.04.2016.

\section{REFERENCES}

Blundell R., Duncan A., McCrae J., Meghir C. (2000), The Labour Market Impact of the Working Families' Tax Credit, "Fiscal Studies", Vol. 21(1), p. 75-104.

Aizer A., Eli S., Ferrie J., Lleras-Muney A. (2016), The long-run impact of cash transfers to poor families, "The American Economic Review", Vol. 106(4), p. 935-971.

Bargain O., Morawski L., Myck M., Socha M. (2007), As SIMPL as that: introducing a tax-benefit microsimulation model for Poland, IZA Discussion Papers 2988, Institute for the Study of Labor (IZA).

Bishop J.A., Grodner A., Liu H., Ahamdanech-Zarco I. (2014), Subjective poverty equivalence scales for Euro zone countries, "The Journal of Economic Inequality", Vol. 12, No. 2, p. 265-278.

Buhmann B., Rainwater L., Schmaus G., Smeeding T.M. (1998), Equivalence Scales, Well-being, Inequality, and Poverty: Sensitivity Estimates Across Ten Countries Using the Luxemburg Income Study (LIS) Database, "Review of Income and Wealth", Vol. 34, Issue 2, p. 115-142.

Carneiro P., Løken K.V., Salvanes K.G. (2015), A Flying Start? Maternity Leave Benefits and Long-Run Outcomes of Children, "Journal of Political Economy", Vol. 123(2), p. 365-412.

Collado D., Cantillon B., Van den Bosch K., Goedemé T., Vandelannoote D. (2017), The end of cheap talk about poverty reduction: the cost of closing the poverty gap while maintaining work incentives, Working Paper No. 16/08, Herman Deleeck Centre for Social Policy, University of Antwerp.

Coulter F.A., Cowell T.M., Jenkins S.P. (1992), Differences in needs and assessment of income distributions, "Bulletin of Economic Research", Vol. 44(2), p. 77-124. 
Domitrz A., Morawski L., Myck M., Semeniuk A. (2012), Dystrybucyjny wplyw reform podatkowo-świadczeniowych wprowadzonych w latach 2006-2011 [The distribution impact of tax-benefit reforms implemented in the years 2006-2011], "Bank i Kredyt", No. 44(3).

Garner T., Short K. (2003), Personal assessments of minimum income and expenses: What do they tell us about 'minimum living' thresholds and equivalence scales?, w: J. Bishop, Y. Amiel (eds.), Inequality, Welfare and Poverty: Theory and Measurement, Research on Economic Inequality, Elsevier, p. 191-243.

Goraus-Tańska K., Inchauste G. (2016), The distributional impact of taxes and transfers in Poland, Policy Research Working Paper; No. WPS 7787, World Bank Group, Washington D.C.

GUS (2017a), Sytuacja gospodarstw domowych w 2016 r. w świetle wyników badania budżetów gospodarstw domowych [The situation of households in 2016 in light of household budget study results], Warsaw.

GUS (2017b), Zasięg ubóstwa ekonomicznego w Polsce w 2016 r., opracowanie sygnalne [The extent of economic poverty in Poland in 2016, lead study], Warsaw.

Haan P., Myck M. (2007), Apply with caution: introducing UK-style in-work support in Germany, "Fiscal Studies", Vol. 28, p. 43-72.

Haan P., Wrohlich K. (2011), Can Child Care Encourage Employment and Fertility? Evidence from a Structural Model, "Labour Economics", Vol. 18(4), p. 498-512.

Inchauste G., Rodas P., Goraus-Tańska K. (2016), Skutki dystrybucyjne programu Rodzina 500 Plus, nieopublikowany raport [Distribution impact of the Family 500+ programme, unpublished report].

Kalbarczyk-Stęclik M., Miśta R., Morawski L. (2017), Subjective equivalence scale - cross-country and time differences, "International Journal of Social Economics", Vol. 44(8), p. 1092-1105.

Miśta R., Morawski L. (2016), Dochód, płeć i wiek a wspólne zamieszkiwanie z rodzicami. Przypadek Polski, Czech, Estonii $i$ Węgier [Income, gender and age, and living together with parents. The case of Poland, Czech Republic, Estonia and Hungary], "Studia Ekonomiczne", No. 2, p. 286-311.
Morawski L. (2016), Regulacyjna skala ekwiwalentności dla gospodarstw domowych w Polsce w latach 2006-2014 [Regulatory equivalence scale for households in Poland in the years 2006-2014], "Gospodarka Narodowa", No. 5, p. 71-89.

Morawski L., Myck M. (2010), 'Klin'-ing up: Effects of Polish Tax Reforms on Those In and on those Out, "Labour Economics", Vol. 17(3), p. 556-566.

Morawski L., Myck M. (2011), Distributional Effects of the Child Tax Credits in Poland and Its Potential Reform, "Ekonomista", No. 6, p. 815-830.

Myck M. (2009), Analizy polskiego systemu podatkowo-zasitkowego z wykorzystaniem modelu mikrosymulacyjnego SIMPL [Analyses of the Polish tax-benefit system using the SIMPL microsimulation model], "Problemy Polityki Społecznej", No. 11, p. 86-107.

Myck M. (2016), Estimating Labour Supply Response to the Introduction of the Family 500+ Programme, CenEA Working Paper Series WP01/16.

Myck M., Kundera M., Najsztub M., Oczkowska M. (2015), Portfele gospodarstw domowych po expose premier Beaty Szydlo, Komentarz CenEA [The wallets of households after the expose of Prime Minister Beata Szydło, CenEA Commentary] 19/11/15.

Myck M., Kurowska A., Kundera M. (2013), Financial Support for Families with Children and its Trade-offs: Balancing Redistribution and Parental Work Incentives, "Baltic Journal of Economics", Vol. 13(2), p. 59-84.

Myck M., Najsztub M. (2015), Data and Model Cross-validation to Improve Accuracy of Microsimulation Results: Estimates for the Polish Household Budget Survey, "International Journal of Microsimulation", Vol. 8(1), p. 33-66.

Myck M., Najsztub M. (2016), Distributional consequences of tax and benefit policies in Poland: 2005-2014, CenEA Working Paper Series WP02/16.

Popova D. (2016), Distributional impacts of cash allowances for children: a microsimulation analysis for Russia and Europe, "Journal of European Social Policy", Vol. 26(3), p. 248-267.

Szarfenberg R. (2017), Wpływ świadczenia wychowawczego (500+) na ubóstwo na podstawie mikrosymulacji [The impact of the child-care benefit $(500+)$ on poverty based on microsimulation], "Polityka Spoteczna", No. 5-6.

\title{
SUMMARY
}

We use the microsimulation approach and household budget survey data from 2015 to estimate the shortterm impact of the "Family 500+" programme on household incomes, poverty and inequality. The results suggest that the programme will have the strongest impact on the incomes of households at the lower end of income distribution. Extreme consumption poverty in the whole population is reduced in the range from 35 to $37 \%$, while child poverty in the range from 75 to $100 \%$, depending on the choice of equivalence scale and assumptions about changes in household expenditures. The paper shows also that the programme will reduce the Gini index of income inequality in Poland by a few percentage points. The programme can lead to a lower risk of extreme poverty for households with children as compared to small households (e.g. single-person households). Analysis based on certain equivalence scales suggests that even before the implementation of the "Family 500+" programme extreme poverty among households with children was comparable or lower than among one-person or childless households. The progressive impact of "Family 500+" programme on income distribution in Poland may be reduced in the longer run if labour market activity of low income households will be affected negatively.

Keywords: child-care benefits, poverty, inequality, microsimulation, equivalence scales

\section{EFFECT OF CHILD CARE BENEFIT $(500+)$ ON POVERTY BASED ON MICROSIMULATION}

\author{
Ryszard Szarfenberg \\ Institute of Social Policy, \\ University of Warsaw, Poland
}

\section{FAMILY POLICY OBJECTIVES}

Reducing the poverty of families and children is not the sole purpose of family policy, and monetary benefits do not exhaust the set of its instruments. Apart from many types of family benefits, there is also a large area of social services dedicated to families and children. Expenditure for such services in Poland is low compared to many countries, which also affects their low availability and limited quality. The integrated family policy is based on a couple of pillars. In addition to supporting parents' economic activity and income support, it includes also the "access to high quality and affordable services".

Several objectives are worth mentioning in this respect, following the recommendation of the European Commission of 20 February 2013 Investing in children: breaking the cycle of marginalization.

1. Reduce the inequality at an early age by investing in early childhood education and childcare.

2. Increase the impact of education systems on equal opportunities. 